\section{Serum retinol binding protein 4 is not decreased in congenital generalized lipodystrophy: a case series}

\author{
Os níveis plasmáticos da retinol binding protein 4 (RBP4) não estão \\ reduzidos na lipodistrofia congênita generalizada: uma série de casos
}

Amélio F. Godoy-Matos ${ }^{1,2}$, Rodrigo O. Moreira', ${ }^{1,2}$, Renata MacDowell',2, Izidro Bendet ${ }^{3}$

\begin{abstract}
Introduction: Previous studies have suggested that Retinol Binding Protein 4 (RPB4), a protein produced by the adipose tissue, is associated with insulin resistance (IR). Congenital Generalized Lipodystrophy $(C G L)$ is a rare disease characterized by IR and paucity of adipose tissue. Our objective was to determine RBP4 levels in patients with CGL. Subjects and methods: Six (6) patients with CGL and a healthy control group were selected to participate in the study. Anthropometric and biochemical variables were compared between groups. Results: No difference was observed in RBP4 levels between the two groups (CGL 42.5 [12.5 - 127] vs. control 57.4 [15.9 - 165]; $p=0.78$ ). On the other hand, leptin levels were significantly lower in CGL patients (CGL 0.65 [0.2 - 0.7] vs. control 10.9 [0.9 - 38.6]; $p=0.015)$. No correlation was found between RBP-4 and waist circunference $(r=$ $0.18, p=0.57)$, or BMI $(r=0.24, p=0.45)$. Conclusion: RBP4 is not decreased in CGL. These results suggest that adipose tissue may not be the main source of RBP4. Arq Bras Endocrinol Metab. 2011;55(4):279-83
\end{abstract}

\section{Keywords}

Retinol binding protein 4; lipodystrophy; obesity

\section{RESUMO}

Introdução: Estudos prévios sugeriram que os níveis plasmáticos da retinol binding protein (RBP4), uma proteína do tecido adiposo, estão associados com a resistência à insulina (RI). A lipodistrofia congênita generalizada (LCG) é uma doença rara caracterizada por ausência de tecido adiposo e RI. O objetivo é determinar os níveis de RBP4 em pacientes com LCG. Sujeitos e métodos: Seis (6) pacientes com LCG e um grupo controle saudável foram selecionados para participar no estudo. As variáveis antropométricas e bioquímicas foram comparadas quando comparados os grupos. Resultados: Nenhuma diferença foi observada entre os níveis de RBP4 log entre os grupos (LCG 42,5 [12,5 - 127] vs. controle 57,4 [15,9-165]; $p=0,78$ ). Por outro lado, os níveis de leptina foram menores em pacientes com LCG (LCG $0,65[0,2-0,7]$ vs. controle 10.9 $[0,9-38,6] ; p=0,015)$. Nenhuma correlação foi encontrada entre RBP4 e cintura $(r=0,18, p=0,57)$ ou IMC ( $r=0,24, p=0,45)$. Conclusão: RBP4 não está diminuída na LCG. Esses resultados sugerem que o tecido adiposo pode não ser a principal fonte de RBP4. Arq Bras Endocrinol Metab. 2011;55(4):279-83

\section{Descritores}

Retinol binding protein 4; lipodistrofia congênita generalizada; obesidade
1 Instituto Estadual de Diabetes e Endocrinologia do Rio de Janeiro (IEDE), Rio de Janeiro, RJ Brazil ${ }^{2}$ Pontifícia Universidade Católica do Rio de Janeiro (PUC-RJ), Rio de Janeiro, RJ, Brazil ${ }^{3}$ Sérgio Franco Medicina Diagnóstica, Rio de Janeiro, RJ, Brazil

Correspondence to: Amélio F. Godoy-Matos Instituto Estadual de Diabetes e Endocrinologia Rua Moncorvo Filho, 90 20211-340 - Rio de Janeiro, RJ, Brazil godoymatos@openlink.com.br

Received on Jan/5/2011 Accepted on Feb/11/2011

\section{INTRODUCTION}

A dipose tissue was traditionally considered only an energy storage organ. Over the past decades, however, it has also emerged as an endocrine organ. It is now recognized that adipose tissue secretes multiple bioactive peptides, known as adipokines, which can influence metabolism in an autocrine and paracrine fashion, as well as by means of systemic pathways $(1,2)$. A significant relationship has already been established between adipose tissue and insulin resistance (IR). In- 
deed, one of the most important regulators of IR in obese patients is glucose-transporter 4 (Glut-4).

In 2001, Abel and cols. (3) developed a mouse model selectively knocked-out for Glut-4 gene in the adipose tissue (adipose GLUT4 -/- mice). Those animals developed IR in muscle and liver, suggesting that impairing glucose uptake by adipose tissue would interrupt a "dialogue" between fat and muscle or liver. Lately, the same group analyzed DNA arrays of adipose-tissue samples from these mice, and showed a substantial increase in mRNA expression of retinol binding protein 4 (RBP4). They also demonstrated that subjects with IR also presented higher RBP4 plasma levels (4). Moreover, injection of RBP4 in rodents or its overexpression impairs glucose uptake by skeletal muscle and increases expression of the gluconeogenic enzyme phosphoenolpyruvate carboxykinase (PEPCK) in the liver, defining a link between RBP4 with insulin and glucose metabolism (4-6).

Previously, RBP4 was known as the specific transport protein for retinol (vitamin A) in the circulation. $\mathrm{RBP} 4$ is a $21-\mathrm{KD}$ a protein that binds to transthyretin to form a complex that prevents its renal clearance $(4,6)$. Since those initial cornerstone reports, several authors have shown that RBP4 correlates to anthropometric indicators of overweight and/or fat distribution (i.e. body mass index and waist-to-hip ratio) $(5,6)$, and associated metabolic abnormalities such as triglyceride levels, systolic blood pressure and low levels of high-density lipoprotein cholesterol (6,7). Further, RBP4 is increased in type 2 diabetes (4). Studies have not conclusively demonstrated if RBP4 plays a causal role in IR and, therefore, will be a future goal for therapy, or if it acts only as a biomarker for type 2 diabetes and insulin resistance $(5,7)$.

One way to investigate the association between adipokines and metabolic diseases would be states of absence (or significant reduction) of fat tissue. One important disease that presents such feature is congenital generalized lipodystrophy (CGF) (8). For instance, it has been shown that leptin is significantly decreased in total lipodystrophy and anorexia nervosa (9-12). To the best of our knowledge, RBP4 has not been studied in such situation. Therefore, we aimed at studying serum RBP4 levels in patients with CGL due to their complete absence of adipose tissue. Considering leptin as a recognized biomarker of body fat, we established this adipokine as an adjustment factor, and obtained a ratio between RBP4 and leptin.

\section{STUDY DESIGN AND METHODS}

\section{Subjects}

Six (6) patients with congenital generalized lipodystrophy were invited to participate in the study. All participants were carefully examined by an experienced endocrinologist, and provided a detailed medical history at baseline evaluation. The protocol was approved by the Ethics Committee of the institution. A written informed consent was obtained from each patient or a legal tutor, after the procedures involved in the study were thoroughly explained.

The group of 6 patients with generalized lipodystrophy presented typical phenotype for generalized lipodystrophy type 1 , characterizing the Berardinelli-Seip Syndrome. A control group was also carefully and sequentially selected in order to match each lipodystrophic patient by sex, BMI and age.

\section{Anthropometrical examination}

All participants had the following anthropometric data recorded: body weight $(\mathrm{kg})$, height $(\mathrm{m})$, body mass index (BMI), waist circumference (WC), waist-to-hip ratio (WHR) and blood pressure. BMI was calculated as weight in kilograms divided by the square of height in meters $\left(\mathrm{kg} / \mathrm{m}^{2}\right)$. Waist circumference was determined at the midpoint between the lowest rib and the iliac crest. WHR was defined as the ratio of waist girth to the largest circumference of the hips, measured at the trochanter major.

\section{Laboratory evaluation}

Blood samples were collected after a 12-hour overnight fasting. Samples were collected for the following assays: plasma glucose, total cholesterol, high-density lipoprotein cholesterol (HDL-c), low-density lipoprotein cholesterol (LDL-c), very low-density lipoprotein cholesterol (VLDL-c) and triglycerides. All assays were carried out in an automated analyzer (Cobas Integra 400, Roche Diagnosis). Serum RBP4 concentrations were measured by an enzyme-linked immunosorbent assay kit (ELISA; BioSource International, Inc., Camarillo, CA). The ELISA system had an intra-assay coefficient of variation of $2.6 \%-9.2 \%$, and an inter-assay coefficient of variation of $3.4 \%-10.2 \%$. Serum leptin was measured by a radioimmunoassay kit (Linco Research, Missouri, USA). Both kits kindly provided by Sergio Franco Medicina Diagnóstica. 


\section{Statistical analysis}

Statistical analysis was performed with GraphPad InStat 3.00 for Windows 95 (GraphPad Software, San Diego, California, USA). Unpaired $t$ test was used for parametric variables, and Mann-Whitney for non-parametric variables. The strength of the linear relationship between two continuous variables was evaluated by means of Pearson's correlation coefficient or Spearman's correlation coefficient. The level of statistical significance was $5 \%$.

\section{RESULTS}

Table 1 presents the individual characteristics of patients and controls. No patient or control individual had blood ties. Three patients in the CGL group (patients 1, 2 and 3 ) had diabetes (lipoatrophic diabetes) and were under treatment with insulin. Patients 4, 5 and 6 have extreme insulin resistance, as measured by HOMA-IR. All patients in the CGL group presented high triglyceride and low HDL-cholesterol levels. Five out of 6 patients in CGL group had liver ultrasound results indicative of steatosis (data not shown).

Table 2 displays the statistical comparisons between CGL group and control patients. RBP-4 levels were not different in CGL patients as a group, when compared to their matched controls $(\mathrm{p}=0.78)$. However, RLR tended to be increased in CGL $(\mathrm{p}=0.064)$. Significant differences were observed in waist-to-hip ratio $(\mathrm{p}=0.02)$, systolic blood pressure $(\mathrm{p}=0.019)$, diastolic blood pressure $(\mathrm{p}=0.052)$, alanine transferase (ALT; $\mathrm{p}=0.002)$; HDL cholesterol $(\mathrm{p}=0.002)$ and triglyce- ride levels $(\mathrm{p}=0.002)$. Glucose and insulin levels were not included for comparison in Table 2 because 3 patients in lipodystrophic group had already been diagnosed with lipoatrophic diabetes.

The relationship between anthropometric indicators of overweight, leptin and RBP-4 was also evaluated in the entire sample. No correlation was found between RBP-4 and waist $(\mathrm{r}=0.18, \mathrm{p}=0.57)$, waist-to-hip ratio $(\mathrm{r}=-0.23, \mathrm{p}=0.46)$ and BMI $(\mathrm{r}=0.24, \mathrm{p}=0.45)$. No correlation was found between RBP-4 and Leptin, either $(\mathrm{r}=0.34, \mathrm{p}=0.27)$.

Table 2. Comparison between control group and patients with congenital generalized lipodystrophy (CGL)

\begin{tabular}{lccc}
\hline & $\begin{array}{c}\text { Control } \\
(\mathbf{n}=\mathbf{6})\end{array}$ & $\begin{array}{c}\text { Congenital } \\
\text { generalized } \\
\text { Lipodystrophy } \\
(\mathbf{n = 6}\end{array}$ & $\mathbf{p}$ \\
\hline Age (years) & $22.7 \pm 18.9$ & $22.3 \pm 18.2$ & 0.97 \\
BMl (kg/m²) & $21.8 \pm 5.1$ & $20.8 \pm 3.4$ & 0.71 \\
Waist (cm) & $74.0 \pm 15.3$ & $72.3 \pm 11.2$ & 0.83 \\
Waist-to-hip ratio & $0.82 \pm 0.06$ & $0.92 \pm 0.06$ & 0.02 \\
SBP (mmHg) & $85.0 \pm 13.7$ & $120.0 \pm 27.5$ & 0.019 \\
DBP (mmHg) & $56.6 \pm 10.3$ & $75.0 \pm 17.6$ & 0.052 \\
HDL Chol. (mg/dL) & $54.0 \pm 11.3$ & $31.6 \pm 2.5$ & 0.002 \\
Tryglicerides (mg/dL) & $64.4 \pm 53.5$ & $236.6 \pm 67.6$ & 0.002 \\
ALT (mg/dL) & $10.1 \pm 3.9$ & $33.6 \pm 13.3$ & 0.002 \\
RBP4 (mg/ml)* & $57.4(15.9-165)$ & $42.5(12.5-127)$ & 0.78 \\
Leptin (ng/ml) & $10.9(0.9-38.6)$ & $0.65(0.2-0.7)$ & 0.015 \\
RLR & $23.9 \pm 25.3$ & $93.4 \pm 80.8$ & 0.064 \\
\hline
\end{tabular}

Data $=$ means $\pm S D$, except where specified. ${ }^{*}$ Data $=$ median (minimum - maximum). BMI: body mass index; SBP: systolic blood pressure; DBP: diastolic blood pressure; ALT: alanine transferase; Chol: cholesterol; RBP4: retinol binding protein - 4; RLR: RBP4/Leptin Ratio.

Table 1. Individual characteristics of patients with congenital generalized lipodystrophy and in the control group

\begin{tabular}{|c|c|c|c|c|c|c|c|c|c|c|c|c|c|}
\hline & Sex & $\begin{array}{c}\text { Age } \\
\text { (years) }\end{array}$ & $\begin{array}{c}\text { BMI } \\
\left(\mathbf{k g} / \mathbf{m}^{2}\right)\end{array}$ & $\begin{array}{c}\text { Waist } \\
\text { (cm) }\end{array}$ & WHR & $\begin{array}{l}\text { Glucose } \\
\text { (mg/dL) }\end{array}$ & НОМА & $\begin{array}{c}\text { HDL } \\
\text { (mg/dL) }\end{array}$ & $\begin{array}{l}\text { Trig. } \\
\text { (mg/dL) }\end{array}$ & $\begin{array}{c}\text { RBP4 } \\
(\mathrm{mg} / \mathrm{mL})\end{array}$ & $\begin{array}{l}\text { Leptin } \\
\text { (ng/mL) }\end{array}$ & RLR & Diabetes \\
\hline Patient 1 & $F$ & 13,3 & 17.7 & 64 & 0.91 & 186 & NA & 29 & 268 & 33.5 & 0.7 & 47.85 & $Y$ \\
\hline Control 1 & $\mathrm{~F}$ & 13,6 & 19.8 & 71 & 0.73 & 86 & 2.53 & 56 & 60 & 15.9 & 20.4 & 0.78 & $\mathrm{~N}$ \\
\hline Patient 2 & $\mathrm{~F}$ & 56 & 25.3 & 90 & 1,02 & 213 & NA & 29 & 282 & 51,6 & 4.7 & 11 & $Y$ \\
\hline Control 2 & $\mathrm{~F}$ & 58 & 27.6 & 94 & 0.87 & 94 & 1.25 & 69 & 90 & 67.2 & 38.6 & 1.74 & $\mathrm{~N}$ \\
\hline Patient 3 & $\mathrm{~F}$ & 30 & 21.5 & 77 & 0.96 & 111 & NA & 31 & 217 & 12.5 & 0.2 & 62.5 & $Y$ \\
\hline Control 3 & $\mathrm{~F}$ & 30 & 26.5 & 86 & 0.81 & 87 & 0.43 & 63 & 57 & 165 & 29.1 & 5.67 & $\mathrm{~N}$ \\
\hline Patient 4 & M & 7.5 & 19.5 & 64 & 0.97 & 87 & 5.5 & 34 & 273 & 20.2 & 0.4 & 50.5 & $\mathrm{~N}$ \\
\hline Control 4 & $M$ & 7.3 & 14.8 & 51 & 0.85 & 72 & 0.36 & 41 & 58 & 47.7 & 1.3 & 36.69 & $\mathrm{~N}$ \\
\hline Patient 5 & $M$ & 15.9 & 24.4 & 78 & 0.85 & 89 & 8.2 & 32 & 273 & 124 & 0.7 & 177.14 & $\mathrm{~N}$ \\
\hline Control 5 & $M$ & 15.9 & 24.5 & 77 & 0.81 & 91 & 0.45 & 41 & 39 & 32.1 & 0.9 & 35.66 & $\mathrm{~N}$ \\
\hline Patient 6 & $\mathrm{~F}$ & 11.4 & 16.9 & 61 & 0.86 & 88 & 14.6 & 35 & 107 & 127 & 0.6 & 211.66 & $\mathrm{~N}$ \\
\hline Control 6 & $\mathrm{~F}$ & 11.4 & 17.8 & 65 & 0.9 & 88 & 1.41 & 54 & 84 & 91.5 & 1.4 & 63.35 & $\mathrm{~N}$ \\
\hline
\end{tabular}

BMI: body mass index; WHR: waist-to-hip ratio; HOMA: homeostasis model assessment; RBP4: retinol binding protein 4; RLR: RBP4/Leptin Ratio; Trig: triglycerides. 


\section{DISCUSSION}

Congenital generalized lipodystrophy is a rare disease characterized by a severe lack of adipose tissue. Therefore, it is an excellent model to study hormones and/ or substances produced by adipocytes. Indeed, patients with CGL present very low levels of some adipokines, including leptin (11).

Over the last few years, RBP-4 appeared as one more adipokine. Several studies have demonstrated that RBP-4 levels correlated directly with anthropometric measurements of adiposity, including BMI and waist circumference (4-6). It was then hypothesized that RBP-4 levels would indirectly indicate the amount of adipose tissue, and that the absence of adipose tissue would be accompanied by reduced levels of RBP4. This was not the case: RBP4 levels in patients with CGL did not differ from a well-matched healthy control group, despite the difference demonstrated in leptin levels (transformed in $\log$ ). A ratio between RBP4 and leptin (RLR) was also calculated, and an increasing tendency was observed $(\mathrm{p}=0.06)$. If RBP4 levels were to be decreased in CGL, one would expect RLR to be decreased, or close to one. Therefore, this finding underscores that RBP4 is really not altered in states of severe paucity of adipose tissue.

Detection of normal levels of RBP4 in patients with CGL indicates that the adipocyte is not the main source for RBP-4; there may be some other cells and/or organs that also participate in the regulation of RBP4 production. Some studies have already indicated that the liver may be the most important regulator of RBP4 levels $(13,14)$. Recently, Stefan and cols. (15) found no association between RBP-4 levels and total, subcutaneous, visceral and intramyocellular fat. On the other hand, RBP-4 was positively and significantly correlated to liver fat.

These findings were also demonstrated in diabetic patients with nonalcoholic fatty liver disease (NAFLD). Patients with NAFLD presented significant higher levels of serum RBP-4 in comparison with patients that did not fit ultrasound criteria for NAFLD (13). Finally, Yagmur and cols. (14) have also demonstrated that RBP-4 levels correlated directly with the severity of chronic liver disease. Indeed, in patients with liver cirrhosis, RBP4 levels correlated negatively with Child-Pugh score and laboratorial indicators of liver function, including albumin levels and bilirrubins (14).

Some findings in our study support the importance of the liver in regulating RBP-4 levels. First, in our CGL group, 5 out of 6 patients presented hepatomegaly, increased levels of ALT and ultrasound evidence of NAFLD. Remarkably, the only patient exhibiting very low levels of serum RBP4 [Table 1 (patient 3; RBP-4 = 12.5 $\mathrm{mcg} / \mathrm{mL}$ )], has developed moderate hepatic failure within few weeks of evaluation. Taken together, these data suggest that the liver, and not adipose tissue, may act as the main determinant of RBP4 concentrations.

This study has some limitations. First, the use of a small sample may impact our results. However, CGL is a rare and well-defined disease and the identification of normal levels of RBP4 in almost all CGL patients is of great value. It may significantly change some previously defined concepts for RBP4. Second, we did not perform any genetic evaluation of our patients. Although this would be important to confirm the diagnosis of CGL, we believe that phenotypic and biochemical characteristics of our patients (presented in tables 1 and 2), specially leptin levels, are sufficient to establish the diagnosis. Third, a reference range for RBP-4 levels, according to gender and age, is still needed. Unfortunately, our population showed a huge variation in age (from 7 to 58 years old), and this may have affected our statistical analysis. Finally, most of the ELISA assays for RBP-4 determination currently available in the market show several discrepancies, and variability may compromises the comparison of results (16). However, this is the most commonly used method in the majority of studies so far.

In conclusion, this study demonstrated that RBP-4 levels are not decreased in patients with CGL and suggests that adipose tissue is not its main source. It also indirectly reinforces the capital role of the liver in relation to circulating RBP4.

Conflict of interest disclosure: Amélio F. Godoy-Matos, Rodrigo O. Moreira and Renata MacDowell declare that there is no conflict of interest Izidro Bendet is a scientific consultant in immunology at Sérgio Franco Medicina Diagnóstica.

\section{REFERENCES}

1. Kershaw EE, Flier JS. Adipose tissue as an endocrine organ. J Clin Endocrinol Metab. 2004;89:2548-56.

2. Ronti T, Lupattelli G, Mannarino E. The endocrine function of adipose tissue: an update. Clin Endocrinol. 2005;64:355-65.

3. Abel ED, Peroni O, Kim JK, Kim YB, Boss O, Hadro E, et al. Adipose-selective targeting of the GLUT4 gene impairs insulin action in muscle and liver. Nature. 2001;409:729-33.

4. Yang Q, GrahamTE, Mody N, Preitner F, Peroni OD, Zabolotny JM, et al. Serum retinol binding protein 4 contributes to insulin resistance in obesity and type 2 diabetes. Nature. 2005;436:356-62. 
5. Polonsky KS. Retinol-binding protein 4 , insulin resistance, and type 2 diabetes. N Eng J Med. 2006;354(24):2596-8.

6. Graham TE, Yang $Q$, Blüher M, Hammarstedt A, Ciaraldi TP, Henry $\mathrm{RR}$, et al. Retinol-binding protein 4 and insulin resistance in lean, obese, and diabetic subjects. N Engl J Med. 2006;354:2552-63.

7. Craig RL, Chu WS, Elbein SC. Retinol binding protein 4 as a candidate gene for type 2 dibetes and prediabetic intermediate traits. Mol Genet Metabol. 2007;90:338-44.

8. Janke J, Engeli S, Boschmann M, Adams F, Böhnke J, Luft FC, et al. Retinol-binding protein 4 in human obesity. Diabetes. 2006;55:2805-10.

9. Garg A. Acquired and inherited lipodystrophies. N Engl J Med. 2004;350:1220-34.

10. Garg A. Gender differences in the prevalence of the metabolic complications in familial partial lipodystrophies. J Clin Endocrinol Metab. 2000;85:1776-82.

11. Haque WA, Shimomura I, Matsuzawa Y, Garg A. Serum adiponectin and leptin levels in patients with lipodystrophies. J Clin Endocrinol Metab. 2002;87:2395-8.
12. Mantzoros C, Flier JS, Lesem MD, Brewerton TD, Jimerson DC. Cerebrospinal fluid leptin in anorexia nervosa: correlation with nutritional status and potential role in resistance to weight gain. J Clin Endocrinol Metab. 1997;82:1845-51.

13. Wu H, Jia W, BaoY, Lu J, Zhu J, Wang R, et al. Serum retinol binding protein 4 and nonalcoholic fatty liver disease in patients with type 2 diabetes mellitus. Diabetes Res Clin Pract. 2008;79:185-90.

14. Yagmur E, Weiskirchen R, Gressner AM, Trautwein C, Tacke F. Insulin resistance in liver cirrhosis is not associated with circulating retinol-binding protein 4. Diabetes Care. 2007;30:1168-72.

15. Stefan N, Hennige AM, Staiger H, Machann J, Schick F, Schleicher $E$, et al. high circulating retinol-binding protein 4 is associated with elevated liver fat, but not with total, subcutaneous, visceral, or intramyocellular fat in humans. Diabetes Care. 2007;30:1173-8.

16. Graham TE, Wason CJ, Blüher M, Kahn BB. Shortcomings in methodology complicate measurements of serum retinol binding protein (RBP4) in insulin-resistant human subjects. Diabetologia. 2007;50:814-23. 